\title{
Online Purchase Behavior of Somali Consumers
}

\begin{tabular}{|c|c|}
\hline ARTICLE INFO & ABSTRACT \\
\hline $\begin{array}{l}\text { Keywords: } \\
\text { Online shopping } \\
\text { Consumer behavior }\end{array}$ & $\begin{array}{l}\text { Purpose - The purpose of this study is to investigate the online buying behavior of Somali } \\
\text { consumers Specifically, it has aimed to 1) identify the magnitude of online shopping adoption of } \\
\text { Somali consumers; 2) investigate the factors that affect online buying behavior of Somalia } \\
\text { consumers. }\end{array}$ \\
\hline $\begin{array}{l}\text { Received } 22 \text { July } 2020 \\
\text { Revised } 29 \text { October } 2020 \\
\text { Accepted } 7 \text { December } 2020\end{array}$ & $\begin{array}{l}\text { Design/methodology/approach - Quantitative research approach was adopted in this study and } \\
\text { total of } 300 \text { questionnaire samples have been distributed to the respondents. The relationship and } \\
\text { data reliability of the influencing factors are significantly reliable and has significant relationships } \\
\text { which justify the study hypothesis. }\end{array}$ \\
\hline $\begin{array}{l}\text { Article Classification: } \\
\text { Research Article }\end{array}$ & $\begin{array}{l}\text { Findings - The findings of the study indicated that } 88 \% \text { of the respondents have used the internet } \\
\text { for more than } 5 \text { years. This shows that Somali consumers use the internet intensively. Results } \\
\text { showed that clothing and accessories }(41.3 \%) \text {, food and drink }(36.0 \%) \text {, computer products and } \\
\text { software }(12.7 \%) \text {, were the commodities respondents usually bought online. Another interesting } \\
\text { result was found when respondent were asked about the frequency of online shopping. It was found } \\
\text { that } 48.7 \% \text { of the respondents indicated that "sometimes" they used the internet for shopping } \\
\text { purpose. While } 43.7 \% \text { of the respondents indicated that they rarely or never used the internet for } \\
\text { shopping purpose. About } 7.6 \% \text { of the respondents use "often" the internet for shopping purpose. } \\
\text { Among factors influencing online buying behavior of the consumers, convenience was ranked with } \\
\text { highest mean value of ( } 4.13) \text {, followed by reputation, Perceived ease of use, while trust ranked with } \\
\text { lowest mean value of (Mean=3.493). }\end{array}$ \\
\hline & $\begin{array}{l}\text { Discussion - The findings of the study indicated that Trust is ranked with lowest mean value of } \\
\text { (Mean=3.493) which means that Somali consumers do not feel safe on doing online shopping. They } \\
\text { do not feel comfortable while shopping online. The results also shows that convenience was ranked } \\
\text { with highest mean value of (4.13), which means that Somali students see online shopping is more } \\
\text { convenient than traditional shopping. }\end{array}$ \\
\hline
\end{tabular}

\section{Introduction.}

As of late, for convenience and economic purposes' internet shopping has become one of the most popular means of buying products and services among consumers. In contrast to traditional shopping, internet shopping does not just make easier the process of exchanging goods and services between sellers and buyers at anyplace and whenever, but also issues a wide scope of products where customers can make choices and a good environment where notions can be exchanged at low costs. Accompanied by developments in internet, e-commerce is of paramount importance as it gives an enterprise irrespective of its size and citizenship an equal opportunity to do business with customers across the globe through the web. Firms are also offered a chance to sell their goods and services online for 24 hours in a day thus minimizing expenses such as those associated with attracting new clients, personnel as well as retail space.

Online shopping has enormously added value to worlds' economies.As per study by Nielsen (2007), it is indicated that over 627 million individuals on the planet have done web based shopping. İn another survey it is demonstrated that about 1.8 billion individuals across the globe have acquired merchandises and services through the web and is conceived that this figure will keep on ascending as the number of internet users is also rising every day (Statista , 2018).

Internet shopping is developing exceptionally in the first world nations, the presence of quick and low priced internet services in these countries has made online retailing a success. Cushman and Wakefield (2013) report that first world nations have greater contributions when it comes to online shopping. According to Madhumita 
et al., (2016) United Kingdom ranks first in this domain seconded by USA and Germany.

On African continent, owing to poverty, cultural obstacles, lack of addresses and well-marked roads, security problems, poor internet infrastructure, low literacy levels and insufficiency of regulative framework, poor banking facilities and among others, the process of adopting this recent technology of online shopping is slow amid customers (Abiodun, and Suraju, 2013).

However, despite all of the above cited problems, trend in online shopping in Africa is anticipated to grow in the near future. There are big hopes that African nations and firms will take advantage of a globe increase in e-commerce which will facilitate economic growth in this countries.According to a research undertaken by American market research and consulting company, it was projected that e-commerce in an African market will climb up to US\$ 50 billion in 2018 from 2013's US\$ 8 billion.

İn comparison with the past, in this technology epoch, companies are giving much focus to customers' needs and demands because customers play a crucial part in the prosperity of any firm prevailing today as they are the ones involved in revenue generation for the companies through purchasing and exerting an influence on other people to procure their goods and services (Khaniwale,2015).Therefore by concentrating much on customers via comprehending their needs and demands and their attitude towards online market, companies can earn competitive advantage or be able to survive in an environment where competition is very high.

Due to rapid increase of online purchasing in the past, fewer purchasers than predicted certainly buy electronically. In reality, increasing number of consumers use the medium to obtain information but not for purchasing products. Moreover, it seems that there are inadequate information on how and why certain groups of consumers engage in online shopping whereas others accept online shopping reluctantly (Kamarulzaman, 2008). So that, Lack of customer acceptance towards new technology remains a big challenge for the marketers. Moreover, online consumer behavior became a contemporary research area with an increasing number of researches in developed countries like US and UK. However, there has been limited number of studies in Africa as well as in Somalia. Therefore, this study aims at investigating factors that impact Somali consumers' online buying behavior and whether these factors influence their online purchasing behavior.

\section{Theoretical Framework}

In this section of the study, the concepts of online shopping and consumer online buying behavior will be addressed.

\subsection{The concept of online shopping}

People view internet shopping as one of the more popular ways of buying goods and services on the internet (Bourlakis et al., 2008). With this type of shopping customers are also offered more information and alternatives with respect to product and price comparison (Butler and Peppard, 1998)). İn addition according to $\mathrm{Yu}$ and $\mathrm{Wu}$ (2007) in the modern era online shopping has helped in offering more satisfaction to consumers especially those questing for speed and convenience

Online shopping has emerged as one of the significant features of the internet epoch. This process ranks third when it comes to internet activity instantly after emailing and web browsing activities (UCLA Center for Communication Policy, 2001). Online Shopping is a kind of electronic commerce in which customers procure products and services directly from a vendor without involving any intermediate on the internet. In people's everyday life the activity of online shopping is being conducted by so many people and most of them favor this form of shopping than the normal one (Bourlakis et al., 2008). With online shopping the process of buying has become easy and very convenient as customers choose the goods and services they desire on the internet just by clicking the mouse. İn so doing the life becomes an easygoing as well.

Online shopping has also been outlined as the process in which clients acquire goods and services from the seller using internet and this include also components of capital flow, information flow and logistics that are germane to this process of selling products and services with the aid of internet (iResearch, 2009).Varma and Agarwal (2014) also defined online shopping as an activity that deals with researching and buying commodities and services via internet. Whereas Monsuwe et al. (2004) viewed it as the buying conduct of customers in which goods and services are acquired using an online store or an internet site designed for 
buying goods or services online. E-shop, web shop, e-store, web store, internet shop, web store, virtual store or online store are some the names given to the process of online shopping.

\subsection{Consumer buying behavior}

Consumer behavior is a very complicated issue and to a great deal is shaped by social and psychological environments. İt has been defined as a study dealing with how consumers or organizations behave with regards to choosing, purchasing and using the goods and services so that to fulfill their needs and wants and the influence these actions have on them as the consumers and the society at large. Contingent on consumer shopping choices consumer behavior differs from one person to another. These buying choices are determined by their shopping behaviors which ultimately are also influenced by psychological and social factors which possess an impact on the decision process to do with buying (Brassington and Pettitt, 2000). Consumer behavior is "how customers react with regards to making buying choices." It is described as a discipline that provides an understanding as to how customers decide when it comes to buying of goods and services under limited resources in the name of effort, time and money.

\subsection{Factors influencing online buying behavior of the consumers}

There are numerous factors that determine the consumer online buying behavior whether in a direct or indirect way .These factors are discussed underneath:

\section{Trust}

According to Husted (1998) over the years the concept of trust has been extensively studied by researchers as it is seen as fundamental component to interactions or associations between people, or between organizations or between the two of these people and organizations. However, till today they are still disagreement among researchers as to what exactly the word trust means. This problem even exist when it comes to basic definitions.

Deutsch, (1958) described trust as an individual's cheerful compliance to depend on another person on the impression that he or she will not deliberately let them down. Others like Morgan and Hunt (1994) have described trust as the process of having faith that the trusted person will behave in a pleasing way. Lewicki et al. (1998) defined it as mutuality existing between two parties or more. In e-commerce trust is also defined as an individual's or a party's willingness to be susceptible to somebody's actions or party contingent on the belief that the other person or party will do a particular task significant to the trustor regardless of monitoring or controlling the other body (Petrovic et al., 2003). This definition signifies that consumers are susceptible to the activities of others depending on the anticipation that they will not be deliberately harmed by the other party. In this case the trustee is the internet seller who is trusted and can capitalize on customers' (trustors) vulnerability.

\section{Convenience}

Convenience is described as effort and time consumers spent in procuring goods and services (Brown 1989). In more briefly sense Brown et al. (1992) defined convenience as a decrease in the amount of time or energy that are spent by consumers while procuring, utilizing and disposing of goods or services in relation to the time and effort that can also be spent while dealing with other offerings from somewhere else.

Empirically researchers have found that one of the factors influencing consumers' willingness to procure goods and services online is the internet convenience (Wang et al., 2005). İn another study by Ganesh et al (2010) it is demonstrated that ease of shopping is one of the most significant grounds as to why customers patronize a virtual store. An implication that this element of ease of shopping or accessibility is one of advantages of online shopping in contrast to traditional shopping (Ganesh et al, 2010: 8).

\section{Company reputation}

The term reputation means the degree to which the purchasers of goods and services conceive that the marketer is an expertly capable, truthful and kind (Jarvenpaa et al., 2000). Reputation communicates to the customers as to how an organization's products and or services differ with other company's products or rivals. Positive reputation is very vital to the company as it attracts new investors, minimize capital expenses and company's competitive advantage also enhances. Organization's reputation is considered by researchers as 
worthful intangible asset that necessitates investment of resources, efforts and attention to client connections in the long term. The vulnerability of reputation exist due to the fact that it is easy to lose a reputation than to form it (Yaniv and Kleinberger, 2000).

\section{Perceived usefulness}

According to Lai and Wang (2012) perceived usefulness is described as the degree to which buyers feel that the online site could increase worth and efficaciousness to them whilst executing web based shopping. It was also defined by Davis (1989) as the extent to which the client conceives that the technology will improve the execution of an activity. Generally website's perceived usefulness is contingent on technological features efficiency like personal service which is offered to customers by service provider and search engines at an advanced level (Kim and Song, 2010). İts a must that that for the clients to make well-informed choices adequate information in addition to great quality product's descriptions be offered to them. (Chen, Gillensonand Sherrell, 2002).

\section{Perceived Ease of Use}

The concept of perceived ease of use refers to the perception by the individual that utilizing the recent technology will require lesser effort or endeavors (Davis, 1989, 1993).Selamat (2009) put it that, people are more likely to accept a technology which is understood to be not hard in terms of using it in comparison to the others. This notion was in line with Teo (2001) who also in his study found that an easy to use system or technology most of times needs less endeavors on the users part hence this increases likeliness of that system or technology to be adopted and used by the people. Other researchers such as Bisdee (2007).Yulihasri and Daud (2011) also noted that the perceived ease of use positively shapes consumers' attitude with regards to using the Internet to buy online (Bisdee, 2007; Yulihasri\&Daud, 2011).

\section{Method}

\subsection{The Purpose and Hypothesis of the Study}

The purpose of this study is to explore and investigate the online buying behavior of Somali consumers specifically, it has aimed to 1) identify the magnitude of online shopping adoption of Somali consumers; 2) investigate the factors that affect online buying behavior of Somali consumers.

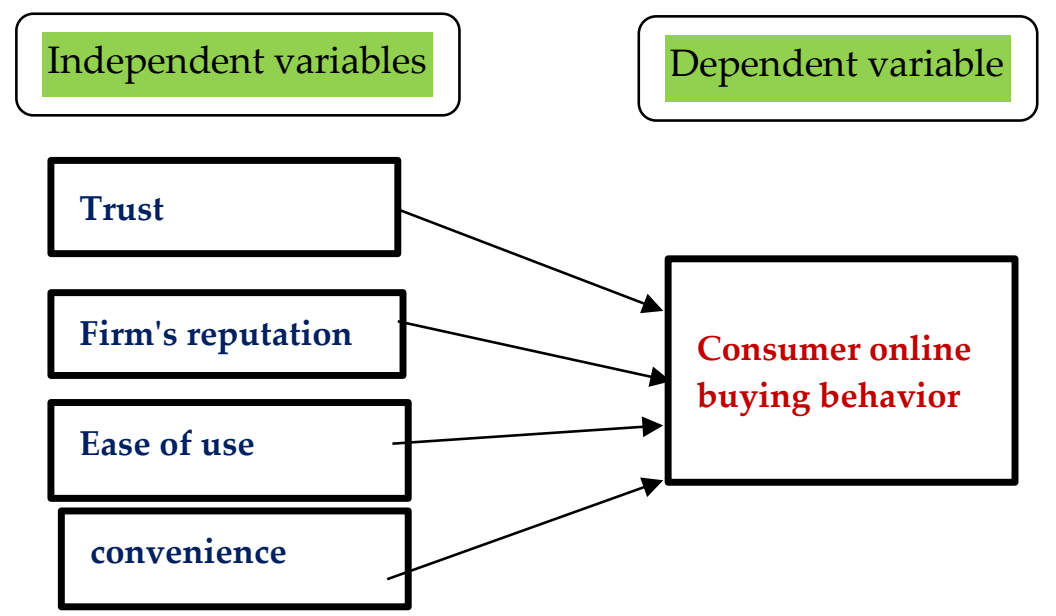

Figure1. Study model

\section{Hypothesis}

H1:There is significant relationship between Trust and online buying behavior of Somali Consumers.

H2:There is significant relationship between Firm Reputation, and online buying behavior of Somali Consumers.

H3:There is significant relationship between ease of use, and online buying behavior of Somali Consumers.

H4:There is significant relationship between convenience, and online buying behavior of Somali Consumers. 


\subsection{Research design and Sample of the research}

A research design is a framework that specifies the details of the procedures necessary for obtaining the information needed to structure or solve the research problem (Malhotra 2007). A research can be differentiated in terms of approach, either by using quantitative or qualitative approach (Neuman, 2003). The aim of this research is to investigate factors that influence Somali consumers' online purchasing behavior. The sample of the study was 300 Consumers. The adopted approach of the study is quantitative study where questionnaire is designed and distributed among consumers from Somalia to collect the data. The questionnaire is prepared based on the past studies and pilot study was conducted. The collected samples was analyzed by using Statistical Package for the Social Sciences software(SPSS) software which is convenient to use and fast to get the results. Frequency, descriptive analysis, and to check reliability of the tool internal consistency method using SPSS by finding Cronbach's alpha value lastly correlation factors was determined.

\section{Finding of the study}

There were 300 respondents who participated and completed the survey questionnaires. Out of these, $69.3 \%$ (208) were men and 30.7\% (92) were women. Five categories were used gathering information about the age of the respondents. Respondents who were in the age group of 21-30 were the majority of the respondents and the total rate is $87.7 \%$ (263), while $3 \%(9)$, of the respondents belong to the age group of $31-40$, and $9.3 \%$ (28), of the respondents belong to the age group of under 20. Age group data of respondents show that the survey mostly represented by a young group. Half of the respondents $(57.3 \%=172$ respondents) have a master's degree, while $34.3 \%$ (103), of the respondents were Bachelor's degree holder, $5.7 \%$ (17), of the respondents were high school and $2.7 \%$ (8) of the respondents attained PhD's.

This study focused on online shopping hence it is also interesting to know the respondents' internet experience. Results showed that majority $(88.0 \%=264$ respondents $)$ of the respondents have been using the internet for more than five years already, while $8.7 \%$ (26) have been using the internet 3-5 years, with only $3.3 \%$ (10 respondents) who just started (i.e. with less than 3 years experience in internet use). Another interesting result was found when frequency of online shopping was analyzed. It was found that $48.7 \%$ (146 respondents) indicated that "sometimes" they used the internet for shopping purpose. Nevertheless, users in the extreme sides, such as those who shop very often and those who never or rarely experienced online shopping also appeared. Intensive users account $7.6 \%$ (23) of the total number of respondents while $43.7 \%(131)$ Accounts for users who rarely or never shop online. Results revealed that clothing and accessories (41.3\%), food and drink $(36.0 \%)$, computer products and software $(12.7 \%)$, were the commodities respondents usually bought online.

Table1: Demographic Analysis

\begin{tabular}{|c|c|c|c|}
\hline Description & Variables & Frequency & $\begin{array}{l}\text { Percentage } \\
(\%)\end{array}$ \\
\hline \multirow[t]{2}{*}{ Gender } & Male & 208 & 69.3 \\
\hline & Female & 92 & 30.7 \\
\hline \multirow[t]{3}{*}{ Age (Years) } & Under 20 & 28 & 9.3 \\
\hline & $21-30$ & 263 & 87.7 \\
\hline & 31 and above & 9 & 3.0 \\
\hline \multirow[t]{4}{*}{ Respondent qualification } & High school & 17 & 5.7 \\
\hline & Bachelor & 103 & 34.3 \\
\hline & Master & 172 & 57.3 \\
\hline & PhD's & 8 & 2.7 \\
\hline \multirow{4}{*}{$\begin{array}{l}\text { How long have you been using the } \\
\text { internet? }\end{array}$} & Less than 1 year & 1 & 0.3 \\
\hline & $1-3$ years & 9 & 3.0 \\
\hline & 3-5 years & 26 & 8.7 \\
\hline & More than 5 years & 264 & 88 \\
\hline
\end{tabular}




\begin{tabular}{|c|c|c|c|}
\hline $\begin{array}{l}\text { Have often do you use the internet for } \\
\text { shopping purpose? }\end{array}$ & $\begin{array}{l}\text { Never } \\
\text { Rarely } \\
\text { Sometimes } \\
\text { Often }\end{array}$ & $\begin{array}{l}3 \\
128 \\
146 \\
23\end{array}$ & $\begin{array}{l}1.0 \\
42.7 \\
48.7 \\
7.6\end{array}$ \\
\hline $\begin{array}{l}\text { Which product group you buy most } \\
\text { over the internet? }\end{array}$ & $\begin{array}{l}\text { CD,DVD,MUSİC, } \\
\text { Computer product and software } \\
\text { Clothing and accessories } \\
\text { Food and drink } \\
\text { Perfume and cosmetic }\end{array}$ & $\begin{array}{l}12 \\
38 \\
124 \\
108 \\
18 \\
\end{array}$ & $\begin{array}{l}4.0 \\
12.7 \\
41.3 \\
36.0 \\
6.0 \\
\end{array}$ \\
\hline
\end{tabular}

\section{Data Reliability Analysis}

For testing the reliability of this study's data we used Cronbach's Alpha test, its value must be between 0 and 1 , and the acceptable value statistical must be more than 0.6. The value of Alpha for 300 participants is 0.881 . As the value is above $70 \%$ or 0.7 which shows that questionnaire used was reliable for information collection.

Table 2. Reliability Test

\begin{tabular}{ll}
\hline Cronbach's Alpha & No. of items \\
\hline 0.881 & 12 \\
\hline
\end{tabular}

Table 3: Descriptive Statistics of convenience

\begin{tabular}{|l|c|c|c|}
\hline & N & Mean & Std. Deviation \\
\hline $\begin{array}{l}\text { Online shopping is more comfortable, because I } \\
\text { can buy products whenever I want. }\end{array}$ & 300 & 4.18 & 1.042 \\
$\begin{array}{l}\text { product information can easily be found in } \\
\text { online shopping sites }\end{array}$ & 300 & 4.2 & 0.777 \\
$\begin{array}{l}\text { It is easy to compare many products in online } \\
\text { shopping }\end{array}$ & 300 & 4.01 & 1.002 \\
\hline
\end{tabular}

Table 4: Descriptive Statistics of perceived ease of use

\begin{tabular}{|l|c|c|c|}
\hline & $\mathrm{N}$ & Mean & Std. Deviation \\
\hline $\begin{array}{l}\text { Online shopping is more convenient than } \\
\text { shopping to physical stores. }\end{array}$ & 300 & 3.82 & 1.01 \\
$\begin{array}{l}\text { Online shopping site designs are attractive and } \\
\text { stimulating. }\end{array}$ & 300 & 3.72 & 1.194 \\
Online shopping sites are easy to use/navigate. & 300 & 4.33 & 0.905 \\
\hline
\end{tabular}

Table 5: Descriptive Statistics of Firm Reputation

\begin{tabular}{|l|l|l|l|l|}
\hline & N & Mean & Std. Deviation \\
\hline Online shopping sites have strong reputations. & 300 & 3.73 & 1.181 \\
$\begin{array}{l}\text { The name value of the firm and product or } \\
\text { services on the website is important for students. } \\
\text { famous sites provide high quality products }\end{array}$ & 300 & 4.24 & 0.977 \\
\hline
\end{tabular}


Table 6: Descriptive Statistics of Trust

\begin{tabular}{|l|c|c|c|}
\hline & N & Mean & Std. Deviation \\
\hline Online shopping is safe and trustworthy & 300 & 2.53 & 1.362 \\
$\begin{array}{l}\text { I believe that Online shopping sites secure the } \\
\text { privacy of information you provide }\end{array}$ & 300 & 3.72 & 1.194 \\
$\begin{array}{l}\text { a good authentication of websites leads me to } \\
\text { shopping frequently from websites }\end{array}$ & 300 & 4.23 & 0.938 \\
\hline
\end{tabular}

\section{Hypotheses Testing}

The researcher test hypotheses through analysis of correlations. The multiple correlation test was run using SPSS and the finding is shown in Table 7 indicated the correlation between Perceived ease of use, Perceived usefulness, Firm Reputation, and Trust is significantly strong. The regression value lies in between -1 to +1 , as stated positive regression shows significantly strong relation. The correlation findings shown in the Table 8 indicated that there is significant relationship among, Perceived ease of use, Perceived usefulness, Firm Reputation, and Trust toward consumer online buying behavior of the students.

Table 7: Correlations analysis

\begin{tabular}{|c|c|c|c|c|c|c|}
\hline & & CBB & EOU & $\mathrm{CON}$ & RE & TR \\
\hline & Pearson Correlation & 1 & $0.546^{* *}$ & $0.726^{* *}$ & $0.672^{* *}$ & $0.497^{* *}$ \\
\hline \multirow[t]{3}{*}{ CBB } & Sig. (2-tailed) & & 0 & 0 & 0 & 0 \\
\hline & $\mathrm{N}$ & 300 & 300 & 300 & 300 & 300 \\
\hline & Pearson correlation & $0.546^{* *}$ & 1 & $0.408^{* * *}$ & $0.688^{*}$ & $0.392^{* *}$ \\
\hline \multirow[t]{3}{*}{ EOU } & Sig. (2 tailed) & 0 & & 0 & 0.037 & 0 \\
\hline & $\mathrm{N}$ & 300 & 300 & 300 & 300 & 300 \\
\hline & Pearson correlation & $0.726^{* *}$ & $0.408^{* *}$ & 1 & $0.743^{* *}$ & $0.472^{* *}$ \\
\hline \multirow[t]{3}{*}{$\mathrm{CON}$} & Sig. (2 tailed) & 0 & 0 & & 0 & 0 \\
\hline & $\mathrm{N}$ & 300 & 300 & 300 & 300 & 300 \\
\hline & Pearson correlation & $0.672^{* *}$ & $0.688^{*}$ & $0.743^{* *}$ & 1 & $0.587^{* * *}$ \\
\hline \multirow[t]{3}{*}{ REP } & Sig. (2 tailed) & 0 & 0.037 & 0 & & 0 \\
\hline & $\mathrm{N}$ & 300 & 300 & 300 & 300 & 300 \\
\hline & Pearson correlation & $0.497^{* *}$ & $0.392^{*}$ & $0.472^{* *}$ & $0.587^{* *}$ & 1 \\
\hline \multirow[t]{2}{*}{ TRUST } & Sig. (2 tailed) & 0 & 0.037 & 0 & 0 & \\
\hline & $\mathrm{N}$ & 300 & 300 & 300 & 300 & 300 \\
\hline
\end{tabular}

${ }^{* *}$ Correlation is significant at 0.01 level (2 tailed)

*Correlation is significant at the 0.05 level (2 tailed)

\subsection{Discussions and Conclusion}

There were 300 respondents who participated and completed the survey questionnaires. Out of these, $69.3 \%$ (208) were men and 30.7\% (92) were women. Five categories were used gathering information about the age of the respondents. Respondents who were in the age group of 21-30 were the majority of the respondents and the total rate is $87.7 \%$ (263), while 3\% (9), of the respondents belong to the age group of $31-40$, and $9.3 \%$ (28), of the respondents belong to the age group of under 20. Age group data of respondents show that the survey mostly represented by a young group. Half of the respondents $(57.3 \%=172$ respondents) have a master's degree, while $34.3 \%$ (103), of the respondents were Bachelor's degree holder, $5.7 \%$ (17), of the respondents were high school and $2.7 \%$ (8) of the respondents attained PhD's.

The purpose of this study is to explore and investigate the online buying behavior of Somali consumers 
specifically, it was aimed to 1) identify the magnitude of online shopping adoption of Somali consumers; 2 ) investigate the factors that affect online buying behavior of Somali consumers. Perceived ease of use, Convenience, Firm Reputation, and Trust are the major factors influencing consumer online buying behavior. Quantitative research approach was adopted in this study and total 300 questionnaire samples have been distributed among Respondents.

The findings of the study indicated that $88.0 \%$ of the respondents have been using the internet for more than 5 years. This shows that Somali students use the internet intensively. Results revealed that clothing and accessories $(41.3 \%)$, food and drink $(36.0 \%)$, computer products and software $(12.7 \%)$, were the commodities respondents usually bought online. Another interesting result was found when frequency of online shopping was analyzed. It was found that $48.7 \%$ (146 respondents) indicated that "sometimes" they used the internet for shopping purpose. Nevertheless, users in the extreme sides, such as those who shop very often and those who never or rarely experienced online shopping also appeared. Intensive users account $7.6 \%$ (23) of the total number of respondents while $43.7 \%$ ( 131) Accounts for users who rarely or never shop online. Study concluded factors influencing of online buying behavior of Somali students. Results also revealed that clothing and accessories $(41.3 \%)$, food and drink $(36.0 \%)$, computer products and software $(12.7 \%)$, were the commodities respondents usually bought online

It was found that convenience was ranked with highest mean value of (4.13), followed by reputation, Perceived ease of use, while trust ranked with lowest mean value of (Mean=3.493). Which means that Somali students do not feel safe on doing online shopping? They do not feel comfortable while shopping online which means that Somali students see online shopping is more convenient than traditional shopping.

\begin{tabular}{|l|l|l|}
\hline & Ranking & Mean \\
\hline Convenience & 1 & 4.13 \\
\hline Firms Reputation & 2 & 3.986 \\
\hline Perceived ease of use & 3 & 3.956 \\
\hline Trust & 4 & 3.493 \\
\hline
\end{tabular}

\section{Significance of the research, Recommendations \& Suggestions:}

Results of this study will be useful to both online retailers as well as researchers because it will help them better understand how consumers' from East African countries behave in online shopping environment. Moreover, the study has explored factors affecting consumers from east Africa especially Somalia to go online shopping. So that the gathered information can be used as basis in crafting suitable marketing decisions and subsequently assist in the development of strategies that upkeep the preferences or needs of the present generation. Moreover, the researchers can use this study as a foundation for future research.

\section{Recommendations \& Suggestions:}

- This study only focused online shopping behavior in Somali. it is recommended that other countries be included for future research.

- The ability to generalize results is restrained. Respondents do not entirely represent the population of interest. They only came from one group which are Somalis. It is also recommended to include respondents other than Somalis.

- The factors affecting consumers' online shopping adoption and behavior considered in this study do not include technological advancement, policies, technology literacy and others. Thus, suggested to include these in further research.

- The sample size was not enough, it is recommended to increase the sample size.

- The variable that is used in this research was also small, it is recommended to increase the variables. 


\section{REFERENCE}

Abiodun, and Suraju, (2013). “Challenges Militating against Adoption of Online Shopping in Retail Industry in Nigeria". Journal of Marketing Management, 1(1), pp. 23-33.

Bourlakis, M., Papagiannidis, S. and Fox, H, (2008). “E-consumer behavior: Past, present and future trajectories of an evolving retail revolution". International Journal of E-Business Research, vol. 4, no. 3, pp.64-67, 69, 71-76.

Butler, P. and Peppard, J, (1998). "Consumer purchasing on the internet: Processes and prospects". European Management Journal, vol. 16, No. 5, pp.600-610.

Brown, L. G. (1989). “the Strategic and Tactical Implications of Convenience in Consumer Product Marketing”. Journal of Consumer Marketing, 6 (3), pp. 13-19.

Brown LG, McEnally MR (1992). "Convenience: Definition, structure, and application". Journal of Marketing Management, 2(2): 47-56.

Brassington, F. and Pettitt, S. (2000). Principles of Marketing. Second Edition, Financial Times Management, Harlow, London.

Bisdee, D. (2007). Consumer Attitudes Review. Office of Fair Trading, June, 1-147.

Cushman and Wakefield Research Publication. (2013, July), Global Perspective on Retail: Online Retailing". Retrieved July 22, 2015, from Cushman and Wakefield Website:http://www.cushmanwakefield.com/ /media/globalrep orts/Global\%20Perspective\%20on\%20Retail\%201st\%20July\% 202013.pdf.

Chen, L., Gillenson, M. L., and Sherrell, D. L. (2002). "Enticing Online Consumers: A Technology Acceptance Perspective". Information \&Management, 39 (8), pp. 705-719.

Davis, F. D., (1989). "Perceived Usefulness, Perceived Ease of Use, and User Acceptance of Information Technology". Management Information Systems Quarterl, 13(3), 319-340.

Davis, F. D., Bagozzi, R. P., and Warshaw, P. R. (1989). “User acceptance of computer technology: A comparison of two theoretical models". Management Science, 35(8), pp. 982-1003.

Frost, and Sullivan (2015).International E-Commerce in Africa: The Way Forward, in Geneva, Switzerland, 2015, ITC, pp. 47.

Ganesh, J., Reynolds, K. E., Luckett, M., \&Pomirleanu, N. (2010). “Online Shopper Motivations, and E-Store Attributes: An Examination of Online Patronage Behavior and Shopper Typologies". Journal of Retailing, 86(1), 106-115.

Husted, (1998). “The ethical limits of trust in business relation' 'Business ethics quarterly, 8(2), pp.233-248.

Johnson, M. D., Gustafsson, A., Andreassen, T. W., Lervik, L., \& Cha, J. (2001). The evolution and future of national customer satisfaction index models [Electronic version]. Retrieved [insert date], from Cornell University, School of Hospitality Administration site: http://scholarship.sha.cornell.edu/articles/715.

Jarvenpaa, S. L., Tractinsky, N., \& Vitale, M. (2000). "Consumer trust in an Internet store".Journal of Information Technology and Management, 1(1-2), 45-71.

Kim, H., Song, J., 2010. “The Quality of Word-of Mouth in the Online Shopping Mall”. Journal of Research in Interactive Marketing, 4(4), 376- 390.

Kamarulzaman, Y. (2008). "Modelling consumer adoption of internet shopping". Communications of the IBIMA, 5(26), 217-227.

Lai, E., Wang, Z., (2012). "An Empirical Research on Factors Affecting Customer Purchasing Behavior Tendency during Online Shopping". Institute of Electrical and Electronics Engineers. pp. 583-586.

Lewicki, Roy J. and Robert J. Bies (1998), “Trust and Distrust: New Relationships and Realities,” Academy of Management Review, 23 (3), 438-58. 
Lim, K.H., Sia, C.L., Lee, M.K.O. and Benbasat, I. (2006). “Do I trust you online, and if so, will I buy? An empirical study of two trust-building strategies", Journal of Management Information Systems, Vol. 23 No. 2, pp. 233-66.

Manali, Kh., (2015). “Consumer Buying Behavior”. International Journal of Innovation and Vol. 14 No. 2, pp. 278-286.

Mübinkiyici, (2012).'Internet shopping behavior of college of education students"'. The Turkish online journal of educational technology - july 2012, volume 11 issue 3, pp.3.

Monsuwe, T.P.Y., Dellaert, B.G.C. and Ruyter, K.D (2004) “What derives consumers to shop online? A literature review", International journal of Service Industry Management, Vol. 15, No.1, pp. 102-21.

Madhumita, N., Ashutosh, G. And Saurav, A. (2016) "An Empirical Investigation into Factor Influencing Indian Customer to Shop Online", vindhya International Journal of Management \& Research (VIJMR), Vol. 2 no.2, pp.9-10.

Malhotra, (2007)."'culture and consumer behavior: toward an understanding of cross- cultural consumer behavior in international marketing". 'Journal of International Consumer Marketing, vol.6, no.2, pp.91127 ,

Nielson, A. C. (2008). World statistics on the number of internet shoppers. Available: http://www.multillingual-search.com/world-statistics-on-the-number-of-internetshoppers/28/01/2008.

Neuman, W.L. (2003). “Social Research Methods: Qualitative and Quantitative Approaches" (5th ed.). Boston: Allyn and Bacon.

Petrovic O. et al, (2003). "Trust in digital transaction". Journal ofbusiness information Vol. 45, No. 1, pp. 53-66

Selamat, Z., Jaffar, N., \& Ong, B. H. (2009). “Technology acceptance in Malaysian banking industry”. European Journal of Economics, Finance and Administrative Sciences, 1(17), 143-155.

Teo, T. S. H. (2001). "Demographic and motivation variables associated with Internet usage activities. Internet Research, 11(2), 125-137. http://dx.doi.org/10.1108/10662240110695089

UCLA (2001), Surveying the Digital Future: Year Two, Center for Communication Policy. Retrieved from www.digitalcenter.org/pdf/InternetReportYearTwo.pdf

Varma, I.G. \& Agarwal, R. (2014). "Online buying behavior of homemakers in Western suburbs of Mumbai and social media influence". Journal of Business and Management, 16(1), 42-65.

Wang, C.L., Ye, L.R., Zhang, Y. and Nguyen, D.D., (2005). "Subscription to fee-based online services: What makes consumer pay for online content?".Journal of Electronic Commerce Research, vol. 6, no. 4, pp.301-311.

$\mathrm{Yu}, \mathrm{T}$. and $\mathrm{Wu}, \mathrm{G}$, (2007), "Determinants of internet shopping behavior: An application of reasoned behavior theory". International Journal of Management, vol. 24, no. 4, pp. 744-762

Yuslihasri, I. A., \&Daud, A. K. (2011). "Factors that influence customers buying intention on shopping online". International Journal of Marketing Studies, 3(1), 128-143.

Yaniv, I., \&Kleinberger, E. (2000). "Advice taking in decision making: Egocentric discounting and reputation formation". Organizational Behavior and Human Decision Processes. Vol. 83, No. 2, November, pp. 260 281, 2000. 